\title{
Corrosion Protection of 6061 Aluminum Alloys by Sol-Gel Coating Modified with ZnLaAl-LDHs
}

\author{
Youbin Wang $1,2, *\left(\mathbb{D}\right.$, Qiuyu Huang ${ }^{1,2}$, Bingtao Zhou ${ }^{1,2}$, Zengyin Yuan ${ }^{1,2}$, Yuezhou Wei ${ }^{1,2}$ \\ and Toyohisa Fujita ${ }^{1,2}$ (D) \\ 1 Guangxi Key Laboratory of Processing for Non-Ferrous Metal and Featured Materials, Guangxi University, \\ Nanning 530004, China; qiuyuhuang0728@163.com (Q.H.); 202010103819@mail.scut.edu.cn (B.Z.); \\ yuanzengyin@126.com (Z.Y.); yzwei@gxu.edu.cn (Y.W.); fujitatoyohisa@gxu.edu.cn (T.F.) \\ 2 School of Resources, Environment and Materials, Guangxi University, Nanning 530004, China \\ * Correspondence: wangyoubin@gxu.edu.cn; Tel.: +86 07713392507
}

Citation: Wang, Y.; Huang, Q.; Zhou, B.; Yuan, Z.; Wei, Y.; Fujita, T.

Corrosion Protection of 6061

Aluminum Alloys by Sol-Gel Coating Modified with ZnLaAl-LDHs.

Coatings 2021, 11, 478. https://

doi.org/10.3390/coatings11040478

Academic Editor: Ludmila

B. Boinovich

Received: 4 March 2021

Accepted: 12 April 2021

Published: 19 April 2021

Publisher's Note: MDPI stays neutral with regard to jurisdictional claims in published maps and institutional affiliations.

Copyright: (c) 2021 by the authors. Licensee MDPI, Basel, Switzerland. This article is an open access article distributed under the terms and conditions of the Creative Commons Attribution (CC BY) license (https:// creativecommons.org/licenses/by/ $4.0 /)$.

\begin{abstract}
In this work, ZnLaAl layered double hydroxides (LDHs) were prepared by the coprecipitation method, and the ZnLaAl-LDHs nanosheets were embedded in sol-gel coating for the corrosion protection of 6061 aluminum alloys. The structure, morphology, and long-term anticorrosion performance of sol-gel coating modified with ZnLaAl-LDHs were investigated. The structure and morphology analysis showed that nanosheets of ZnLaAl-LDHs are finer than those of ZnAl-LDHs, with the results suggesting that the La can refine the size of LDHs' nanosheets and improve their nucleation rate. The results of long-term corrosion tests showed that the sol-gel coating with ZnLaAl-LDHs exhibits higher corrosion resistance and better stability compared with the sol-gel coating with ZnAl-LDHs, which indicates that the addition of La enhances the anti-corrosion performance of the LDHs and improves the stability of sol-gel coating with LDHs. Finally, the formation mechanism of ZnLaAl-LDHs and the corrosion mechanism of sol-gel coating with ZnLaAl-LDHs on 6061 aluminum alloys are both discussed in detail.
\end{abstract}

Keywords: ZnAl-LDHs; lanthanum; aluminum alloys; corrosion behavior

\section{Introduction}

Aluminum alloys have found extensive applications in the aerospace industry, power industry, automobile manufacturing, construction, food industry and marine shipbuilding industry due to their high strength to weight ratio, high thermal conductivity and processing, and low cost [1,2]. Unfortunately, when aluminum alloys are exposed to chloride-containing environment, pitting corrosion easily appears [3], as well as intergranular corrosion [4] and stress corrosion cracking [5]. In this case, numerous surface treatments have been studied to protect aluminum alloys, such as anodic oxidation [6,7], polymer coating [8,9], silane coating [10-12] and chemical conversion film technology [13,14]. Among the above technologies of surface treatments, chemical conversion films have attracted considerable attention due to their advantages of low cost and simple operation. As a new chemical conversion film, layered double hydroxides (LDHs) film has the characteristics of environmental friendliness and excellent corrosion resistance. Many scholars have begun to study its application in the corrosion protection of aluminum alloys and find LDHs film can provide excellent protection of aluminum alloys.

Layered double hydroxides (LDHs), also known as like-hydrotalcite, is an inorganic functional material with a structure composed of positively charged octahedrons [15]. Its general formula is [M(II) $\left.)_{1-x} \mathrm{M}(\mathrm{III})_{x}(\mathrm{OH})_{2}\right]^{x+}\left(\mathrm{A}^{n-}\right)_{x / n} \cdot \mathrm{mH}_{2} \mathrm{O}$ [16]. LDHs exhibits similar structure to that of brucite when some of the divalent metal cations $\mathrm{M}(\mathrm{II})$ are replaced by the trivalent metal cations $\mathrm{M}(\mathrm{III})$. Excess positive charge is compensated by interlaminar anions $\left(\mathrm{A}^{n-}=\mathrm{CO}_{3}{ }^{2-}, \mathrm{NO}_{3}{ }^{-}, \mathrm{Cl}^{-}\right.$, etc. $)$. Many methods have been developed for preparing $\mathrm{LDHs}$ 
film [17], such as the in-situ growth method [18,19], co-precipitation method [20,21], electrodeposition method, etc. [22,23]. Among the above preparation methods, co-precipitation has the advantage of efficiency and low-cost. J.M. Vega et al. [24]. synthesized ZnAl-LDHs film on the aluminum alloys using the co-precipitation method which inhibited the corrosion of the alloys. Zhang Fen [21] et al. also prepared MgAl-LDHs film on AZ31 alloys by co-precipitation method, and demonstrated that the resulting films exhibit good corrosion resistance.

Recently, in order to improve the corrosion protection performance of ZnAl-LDHs film, some scholars attempted to insert rare earth elements into ZnAl-LDHs. The Ce-doped $\mathrm{ZnCeAl-LDHs}$ was prepared and it was found that the $\mathrm{ZnCeAl-LDHs}$ has better corrosion protection performance [25-27] than that of ZnAl-LDHs. In previous works, our research group [28] prepared ZnLaAl-LDHs by the in-situ growth method, and found that the La can refine ZnLaAl-LDHs nanosheets and improve the corrosion protection performance. LDHs can also be used as corrosion inhibitors to enhance the active anticorrosion of the sol-gel coatings [29,30]. According to the authors, the corrosion protection performance of sol-gel coating modified with ZnLaAl-LDHs has not been systematically studied.

In the present work, the sol-gel coatings with La-doped ZnAl-LDHs were prepared on the surface of 6061 aluminum alloys. Then, titrator, scanning electron microscopy (SEM), X-ray diffraction (XRD) and X-ray photoelectron spectroscopy (XPS) were used to study the effect of doped La content on the microstructure of ZnAl-LDHs prepared by co-precipitation. In order to understand the anticorrosion behavior of sol-gel coatings with ZnLaAl-LDHs, the 6061 aluminum alloys with LDHs/sol-gel coatings were evaluated by Electrochemical impedance spectroscopy (EIS) in $3.5 \mathrm{wt} \% \mathrm{NaCl}$ solution. Finally, the corrosion protection mechanism of the ZnLaAl-LDHs/sol-gel coating on the 6061 aluminum alloys was discussed in detail.

\section{Experimental}

\subsection{Materials and Preparation}

A total of 6061 aluminum alloys were cut into specimens with the size of $\Phi 14 \mathrm{~mm} \times$ $5 \mathrm{~mm}$. The specimens were ground step by step with 200\#, 600\#, 800\#, 1200\# SiC papers until the surface had no obvious scratches, and then polished with $0.1 \mu \mathrm{m}$ diamond slurry. Finally, ultrasonic cleaning was conducted with high pure water and blow-drying.

Configuration of solution: $\mathrm{Zn}, \mathrm{Al}$ nitrates, and $\mathrm{Zn}, \mathrm{Al}$, La nitrates were dissolved in $100 \mathrm{~mL}$ (the total concentration is $0.75 \mathrm{M}$, which $\mathrm{M}$ (II)/M (III) = 2:1), respectively. The solution of $\mathrm{Zn}, \mathrm{Al}$, and $\mathrm{La}$ nitrates had the ration of $\mathrm{La}^{3+} / \mathrm{A}^{3+}=x(x=1 / 5,1 / 3$ and $1 / 1)$. Then, the above solution was added to $0.1 \mathrm{M} \mathrm{NaNO}_{3}$ solution $(200 \mathrm{~mL}, \mathrm{pH}=10.0)$ drop by drop under vigorous stirring. The $\mathrm{pH}$ of the reaction process was controlled to $10.5 \pm 0.2$ by continuous addition of $2 \mathrm{M} \mathrm{NaOH}$. Nitrogen atmosphere was maintained during the experiment to avoid carbonate anion pollution. The final white colloid was then obtained by placing it at $65^{\circ} \mathrm{C}$ for $18 \mathrm{~h}$. Then, the specimens were washed four times with distilled water and filtered. Finally, the washed white colloid was dried at $60^{\circ} \mathrm{C}$ for $12 \mathrm{~h}$. The LDHs powders were named ZnAl-LDHs, ZnLaAl-LDHs-1/5, ZnLaAl-LDHs-1/3 and ZnLaAl-LDHs-1/1, respectively.

The mixed organic-inorganic sol-gel coating was configured as the carrier of LDHs, and the sol-gel coating were prepared by two different sols: the first sol was prepared by mixing and stirring propyl trimethyl silicane (GPTMS), ethanol and deionized water at a volume ratio of 1:3.5:1 $(240 \mathrm{r} / \mathrm{min}, 1 \mathrm{~h})$; The second sol was prepared by mixing and stirring ethanol, acetic acid and zirconium n-propoxide (TPOZ, propanol, 70\% propanol) at a volume ratio of 3:2:1 $(240 \mathrm{r} / \mathrm{min}, 1 \mathrm{~h})$; the last step involved mixing and stirring the above two sols $(240 \mathrm{r} / \mathrm{min}, 0.5 \mathrm{~h}$ ). The final sol was divided into two parts: (a) One part of the sol was left without any treatment and coated on 6061 aluminum alloys substrate named sol-gel; (b) the other part of the sol was stirred with $3 \mathrm{mg} / \mathrm{mL}$ LDHs powders. The 6061 aluminum alloys substrate coated with LDHs/sol-gel coating named ZnAl-LDHs/sol-gel, ZnLaAl-LDHs-(1/5, 1/3 and 1/1)/sol-gel. To prepare the 6061 aluminum alloys with 
sol-gel coating, the alloys substrate soaked in the final sol-gel solution for $5 \mathrm{~min}$, and then drawn out at a speed of $10 \mathrm{~cm} / \mathrm{min}$. These specimens were stood in air for $15 \mathrm{~min}$, and then dried at $60{ }^{\circ} \mathrm{C}$ for $3 \mathrm{~h}$.

The 6061 aluminum alloys with sol-gel coating were immersed in $3.5 \mathrm{wt} . \% \mathrm{NaCl}$ solution at $25^{\circ} \mathrm{C}$ for $168 \mathrm{~h}$. Finally, specimens were removed from the $\mathrm{NaCl}$ solution, rinsed with distilled water, and then dried at room temperature.

\subsection{Characterization}

Titration experiments were conducted with a titrator (Metrohm Tiamo 905, Metrohm, Herisau, Switzerland) using $1 \mathrm{M} \mathrm{NaOH}$ solution as a titration solution, and the drop acceleration was $0.1 \mathrm{~mL} / \mathrm{min}$. The $\mathrm{pH}$ evolution was recorded using Tiamo 2.5 titration software (Metrohm, Herisau, Switzerland). The test solution was mixed with metallic nitrate solution, with an initial volume of $100 \mathrm{~mL}$.

The LDHs powders were characterized by XRD (D/MAX 2500 V, Rigaku, Tokyo, Japan) using the $\mathrm{Cu} \mathrm{K} \alpha$ radiation. The scanning rate was $8^{\circ} \mathrm{min}^{-1}$. The evaluation of the data was done using the Jade 6.5 software (MDI, Burbank, CA, USA). The chemical compositions of LDHs powders were probed using XPS (ESCALAB 250Xi, ThermoFisher, Waltham, MA, USA) with $\mathrm{Al} \mathrm{K} \alpha$ radiation $(1486.6 \mathrm{eV})$. The experimental data were assessed by XPSpeak4.1 software to analyze the chemical composition of LDHs powders. The morphology and cross section of LDHs powders and LDHs/sol-gel coatings (before and after $168 \mathrm{~h}$ immersion) were investigated by SEM (SU8220, Hitachi, Japan).

Electrochemical experiments were carried out using electrochemical workstation (PARSTAT 4000 A, Ametek, Bowen, PA, USA) in $3.5 \mathrm{wt} . \% \mathrm{NaCl}$ solution at room temperature. A classic three-electrode system was adopted: the specimens, $\mathrm{Pt}$ sheet and a saturated calomel electrode (SCE) were used as the working electrode, counter electrode and reference electrode, respectively. All the specimens were sealed by epoxy resin but leaving the testing surface $\left(1 \mathrm{~cm}^{2}\right)$ uncovered for the corrosion tests. Electrochemical impedance spectroscopy (EIS) was tested with the amplitude of $10 \mathrm{mV}$ and the frequency range from $10^{5}$ to $10^{-2} \mathrm{~Hz}$. Finally, the experimental data were fitted by using ZSimpWin 3.1 software (Ametek, Bowen, PA, USA).

In order to ensure the repeatability of the experiment, all the experiments were conducted three times.

\section{Results and Discussion}

\subsection{Preliminary Titrations}

In order to detect the range of $\mathrm{pH}$ that is needed for co-precipitation, the titration experiment of metal salt solution, which was used to prepare LDHs, was conducted. Figure 1 shows the titration curve of different metal salt solutions using $1 \mathrm{M} \mathrm{NaOH}$. It can be seen from the compared titration curves that a plateau appears in all curves at $\mathrm{pH}$ values of 3.6 and 5.2 , respectively.

The emergence of the plateau at $\mathrm{pH}=3.6$ is due to $\mathrm{Al}^{3+}$ consuming $\mathrm{OH}^{-}$to produce $\mathrm{Al}(\mathrm{OH})_{3}$ (Equation (1)), and this plateau shortened with the reduction in the Al content (curves of 1 to 4); the emergence of the plateau at $\mathrm{pH}=5.2$ is due to multiple action (Equations (2)-(5)): $\mathrm{Zn}$ reacts with $\mathrm{OH}^{-}$to form $\mathrm{Zn}(\mathrm{OH})^{+}$, the $\mathrm{Al}(\mathrm{OH})_{3}$ convers to $\mathrm{Al}(\mathrm{OH})_{4}{ }^{-}$, and the LDHs generate during the process. The $\mathrm{La}^{3+}$ participates in the formation of $\mathrm{ZnLaAl}-\mathrm{LDH}$ simultaneously during the plateau at $\mathrm{pH}=5.2$. Moreover, with the addition of $\mathrm{La}^{3+}$ (curves $2-4$ ), a supplementary plateau at $\mathrm{pH}$ around 8 is observed due to the formation of $\mathrm{La}(\mathrm{OH})_{3}$.

$$
\begin{gathered}
\mathrm{Al}^{3+}+3 \mathrm{OH}^{-} \rightarrow \mathrm{Al}(\mathrm{OH})_{3} \\
\mathrm{Al}(\mathrm{OH})_{3}+(\mathrm{OH})^{-} \rightarrow \mathrm{Al}(\mathrm{OH})_{4} \\
\mathrm{Zn}^{2+}+\mathrm{OH}^{-} \rightarrow \mathrm{Zn}(\mathrm{OH})^{+} \\
\mathrm{Al}(\mathrm{OH})_{4}^{-}+3 \mathrm{Zn}(\mathrm{OH})^{+}+\mathrm{OH}^{-}+\mathrm{NO}_{3}^{-}+\mathrm{H}_{2} \mathrm{O} \rightarrow \mathrm{ZnAl}-\mathrm{LDHs}
\end{gathered}
$$




$$
\mathrm{Al}(\mathrm{OH})_{4}^{-}+4 \mathrm{Zn}(\mathrm{OH})^{+}+\mathrm{La}^{3+}+5 \mathrm{OH}^{-}+\mathrm{NO}_{3}^{-}+\mathrm{H}_{2} \mathrm{O} \rightarrow \mathrm{ZnLaAl}-\mathrm{LDHs}
$$

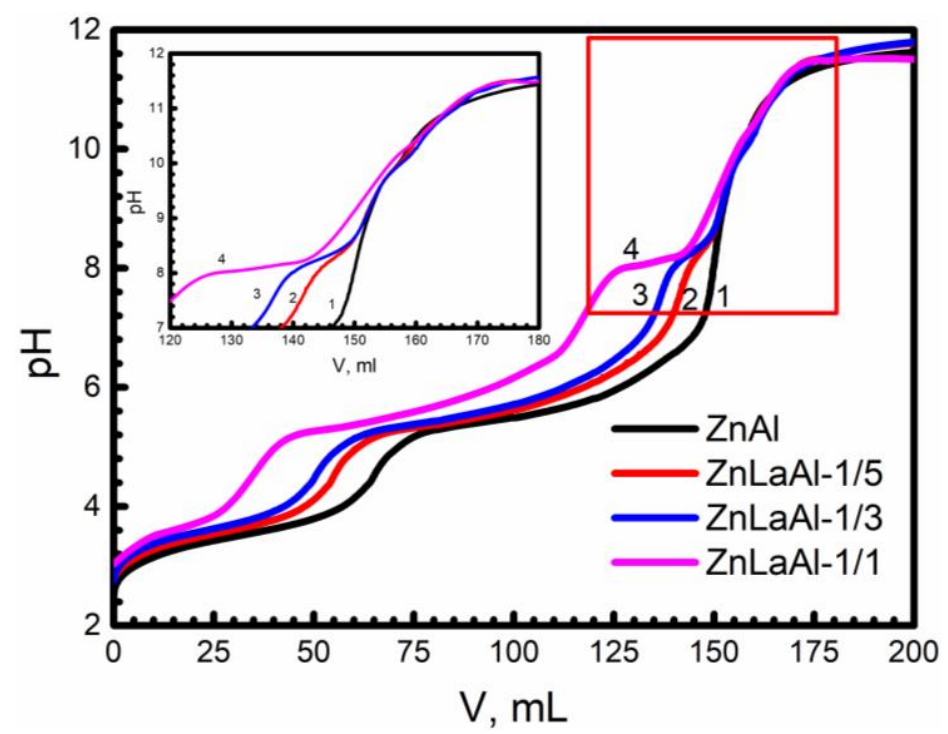

Figure 1. Titration curves of the mixed salt solution with adding the titrant (1.0 M NaOH): (1)

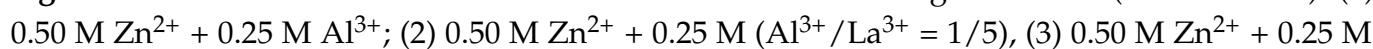
$\left(\mathrm{Al}^{3+} / \mathrm{La}^{3+}=1 / 3\right)$, (4) $0.50 \mathrm{M} \mathrm{Zn}^{2+}+0.25 \mathrm{M}\left(\mathrm{Al}^{3+} / \mathrm{La}^{3+}=1 / 1\right)$; the inset is the magnified patterns of the selected area.

\subsection{Characterization of LDHs Powders}

Figure 2 shows the XRD patterns of the different LDHs powders. The (003), (006) and (110) reflection characteristics of the $\mathrm{ZnAl}-\mathrm{LDHs}-\mathrm{NO}_{3}$ can be observed at $10^{\circ}, 20^{\circ}$ and $60^{\circ}$ [31,32], indicating that $\mathrm{ZnAl}-\mathrm{LDHs}-\mathrm{NO}_{3}$ has been successfully prepared by the co-precipitation method. The impurities of $\mathrm{Zn}(\mathrm{OH})_{2}$ and $\mathrm{ZnO}$ are detected in the $\mathrm{ZnAl}-$ LDHs powder. At the same time, we found that the $\mathrm{La}(\mathrm{OH})_{3}$ appears after doped $\mathrm{La}$ [28], which may be attributed to the fact that not all La cations enter into ZnAl-LDHs. This result is similar to the Ce-doped $\mathrm{ZnAl}-\mathrm{LDHs}$ [25]. Otherwise, the impurity of $\mathrm{Zn}(\mathrm{OH})_{2}$ in the $\mathrm{ZnLaAl}-\mathrm{LDH}$ powder decreases after doped $\mathrm{La}$, and the change of $\mathrm{ZnO}$ is not obvious. The above phenomenon illustrates that the addition of La can inhibit the formation of $\mathrm{Zn}(\mathrm{OH})_{2}$.

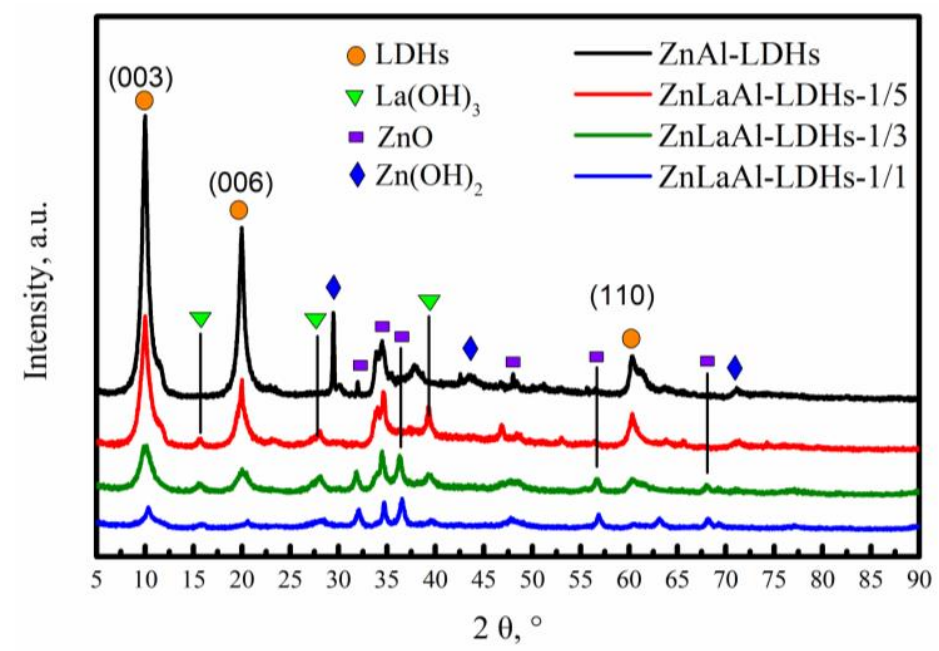

Figure 2. XRD spectra of different LDHs powders prepared by co-precipitation method.

XPS has been performed to explore the composition of the different LDHs powders (Figure 3). From Figure 3a, it is obvious that the peak of $\mathrm{Zn} 2 \mathrm{p}_{3 / 2}$ shifts to the lower binding 
energy with the increase in La content. According to the XPS database and literature [33,34], the peaks of $\mathrm{ZnO}$ and LDHs occur at 1021.2 and $1022.7 \mathrm{eV}$, respectively. The shift of the peak of $\mathrm{Zn} 2 \mathrm{p}_{3 / 2}$ indicates that the content of $\mathrm{ZnO}$ gradually increases with the increasing of the La content. As can be seen in Figure 3b, the binding energy of $\mathrm{Al} 2 \mathrm{p}$ at $73.8 \mathrm{eV}$ can be attributed to ZnAl-LDHs [35]. In addition, with the increasing of the doped La content during the preparation process, the content of $\mathrm{Al}(\mathrm{OH})_{3}$ in the compound decreases. It can be observed from Figure $3 \mathrm{c}$ that the La $3 \mathrm{~d}$ peak in the spectra of ZnLaAl-LDHs occurs at $835.85 \mathrm{eV}$, which corresponds to the peak of $\mathrm{La}(\mathrm{OH})_{3}$ [28].

(a)

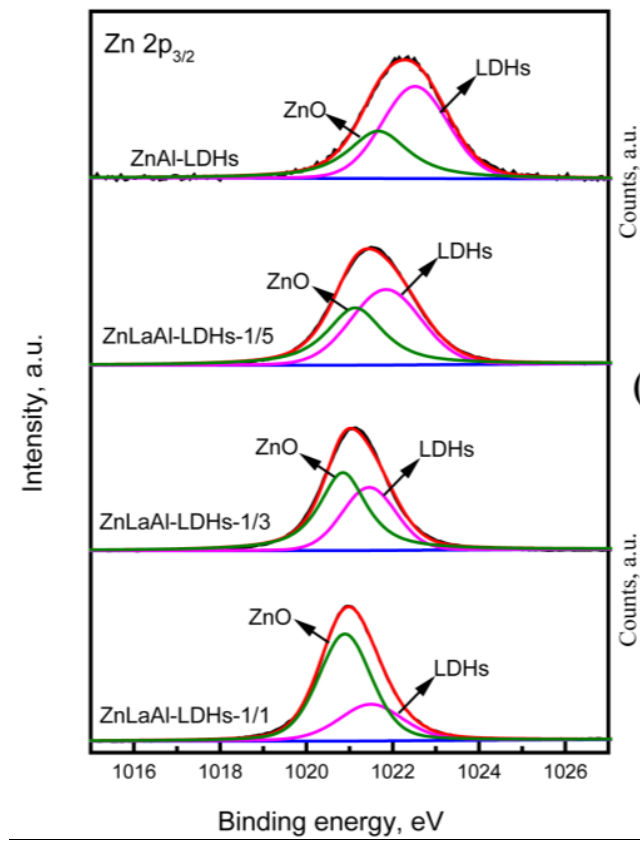

(b)

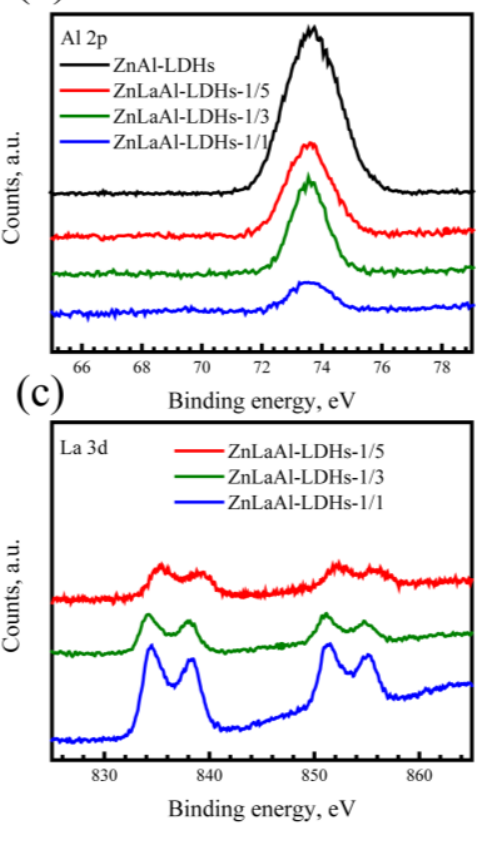

Figure 3. The (a) Zn 2 $\mathrm{p}_{3 / 2}$, (b) Al 2p and (c) La 3d high resolution XPS spectra of the different LDHs powders.

Figure 4 shows the SEM microstructures of different LDHs powders, and the corresponding EDS spectra of ZnAl-LDHs, ZnLaAl-LDHs-1/5, ZnLaAl-LDHs-1/3 and ZnLaAlLDHs-1/1. The ZnAl-LDHs and ZnLaAl-LDHs powders consists of numerous nanosheets, which agrees with the typical morphology of LDHs prepared by co-precipitation method [26]. Figure $4 \mathrm{a}_{1}-\mathrm{d}_{1}$ reveal the morphology change of ZnLaAl-LDHs with different La content: the size of the ZnLaAl-LDHs nanosheets becomes smaller after La-doping, and this phenomenon is more obvious with the increasing of the La content. This phenomenon indicates that La plays the role of refining $\mathrm{ZnLaAl}-\mathrm{LDH}$ nanosheets and inhibiting the crystal growth of LDHs.

The corresponding EDS spectra of selected areas (A, B, C and D) in different LDHs powders are shown in Figure $4 \mathrm{a}_{2}-\mathrm{d}_{2}$, respectively. The results show that $\mathrm{Zn}, \mathrm{Al}, \mathrm{N}$ and $\mathrm{O}$ elements are detected in ZnAl-LDHs and ZnLaAl-LDHs powder, and La element is just detected in ZnLaAl-LDHs powders, which indicates that the La element successfully inserts in the structure of LDHs during the preparation process of co-precipitation. The $[\mathrm{M}(\mathrm{III})] /[\mathrm{M}(\mathrm{II})]$ ratio of LDHs is generally between 0.25 and 1.0 [36-38]. The [M(III)]/[ $\mathrm{M}(\mathrm{II})]$ ratios of ZnAl-LDHs and ZnLaAl-LDHs are both between 0.25 and 1, and the content of $\mathrm{La}$ in LDHs was increased with the increasing of the doping content of La. 


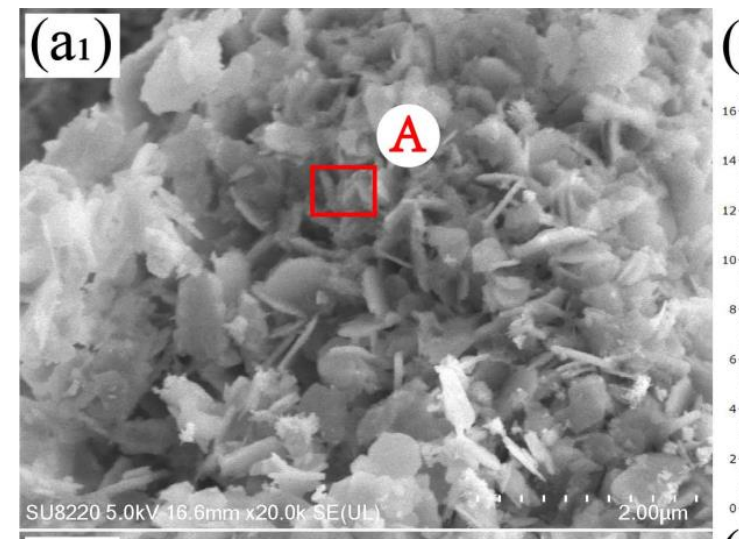

$\left(\mathrm{a}_{2}\right)$

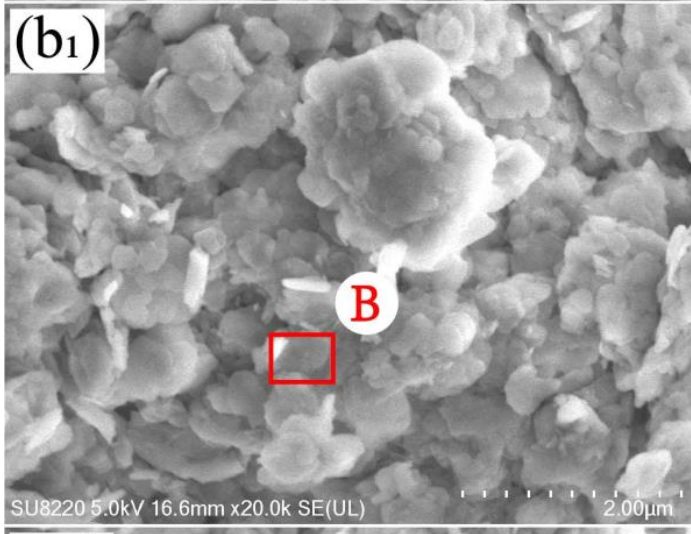

$\left(\mathrm{b}_{2}\right)$
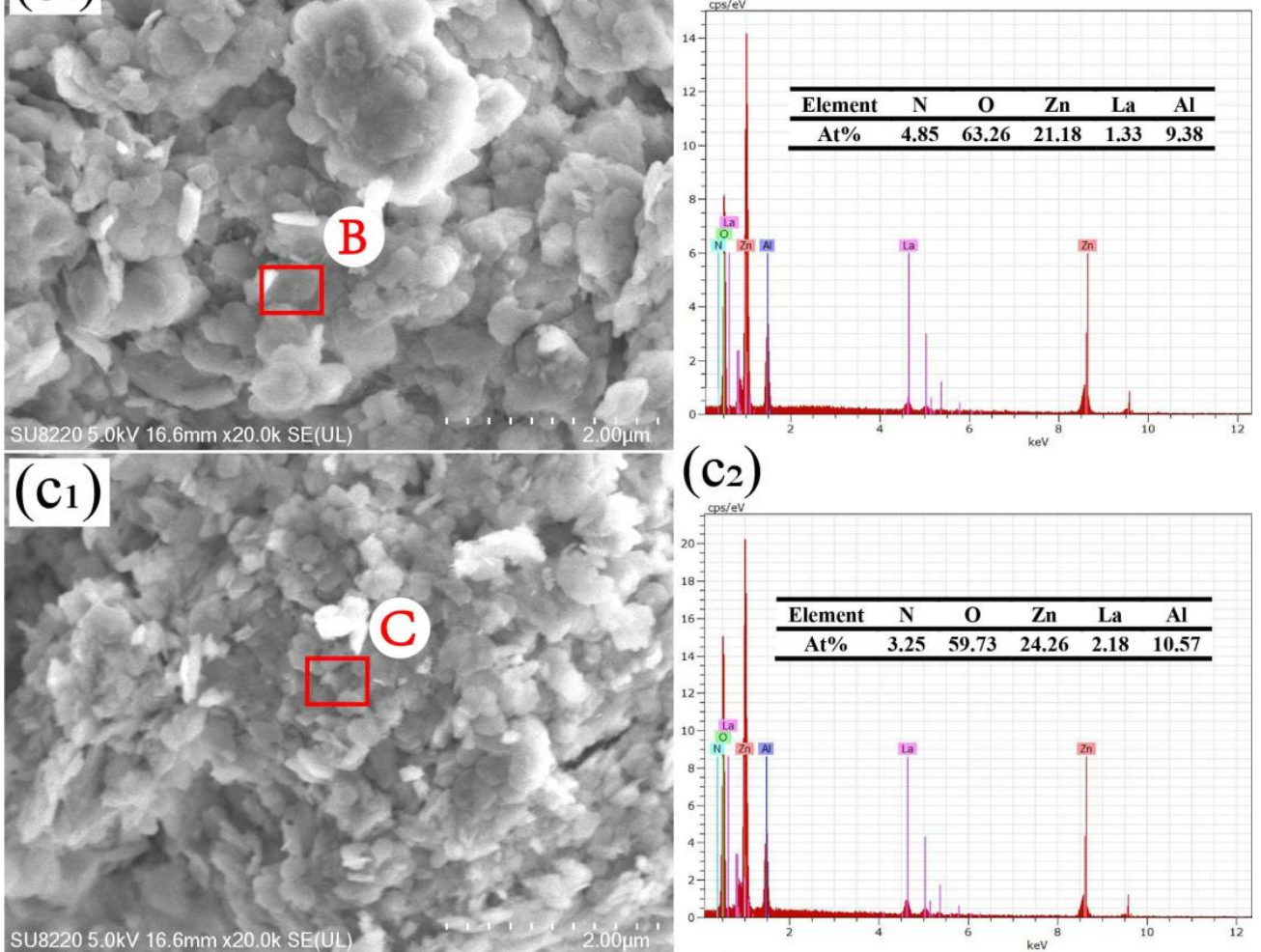

$\left(\mathrm{c}_{2}\right)$

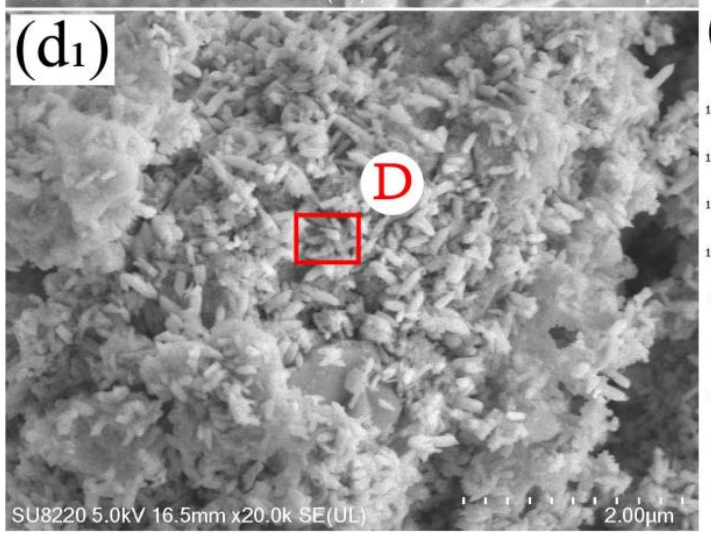

$\left(\mathrm{d}_{2}\right)$
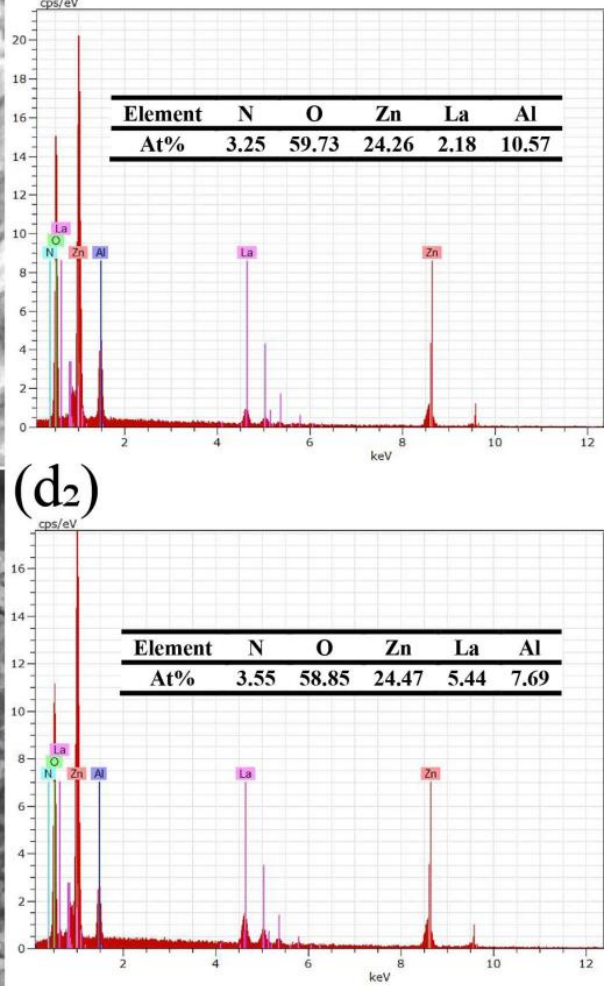

Figure 4. SEM morphologies of different LDHs powders prepared by co-precipitation method:

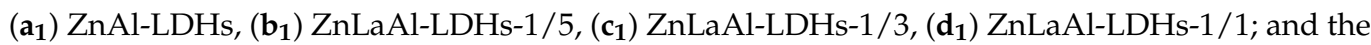
corresponding EDS spectra of selected areas (A, B, C and D) are shown as $\left(\mathbf{a}_{2}-\mathbf{d}_{2}\right)$, respectively. 


\subsection{Corrosion Behavior}

In order to explore the corrosion protection of different LDHs/sol-gel coatings for the 6061 aluminum alloys, Figures 5 and 6 show the surface and cross section morphology of 6061 aluminum alloys with different LDHs/sol-gel coatings immersed in $3.5 \mathrm{wt} . \% \mathrm{NaCl}$ solution. According to Figure $5 a_{1}-a_{5}$, the different LDHs powders are evenly distributed in sol-gel coating, and its surface does not have any obvious cracks, pores and other defects. The cross section (Figure $5 b_{1}-b_{5}$ ) shows that the thickness of sol-gel coating modified with LDHs powders is about $3.5 \mu \mathrm{m}$; there is no obvious differences compared with sol-gel coating modified without LDHs powders $(3.2 \mu \mathrm{m})$.

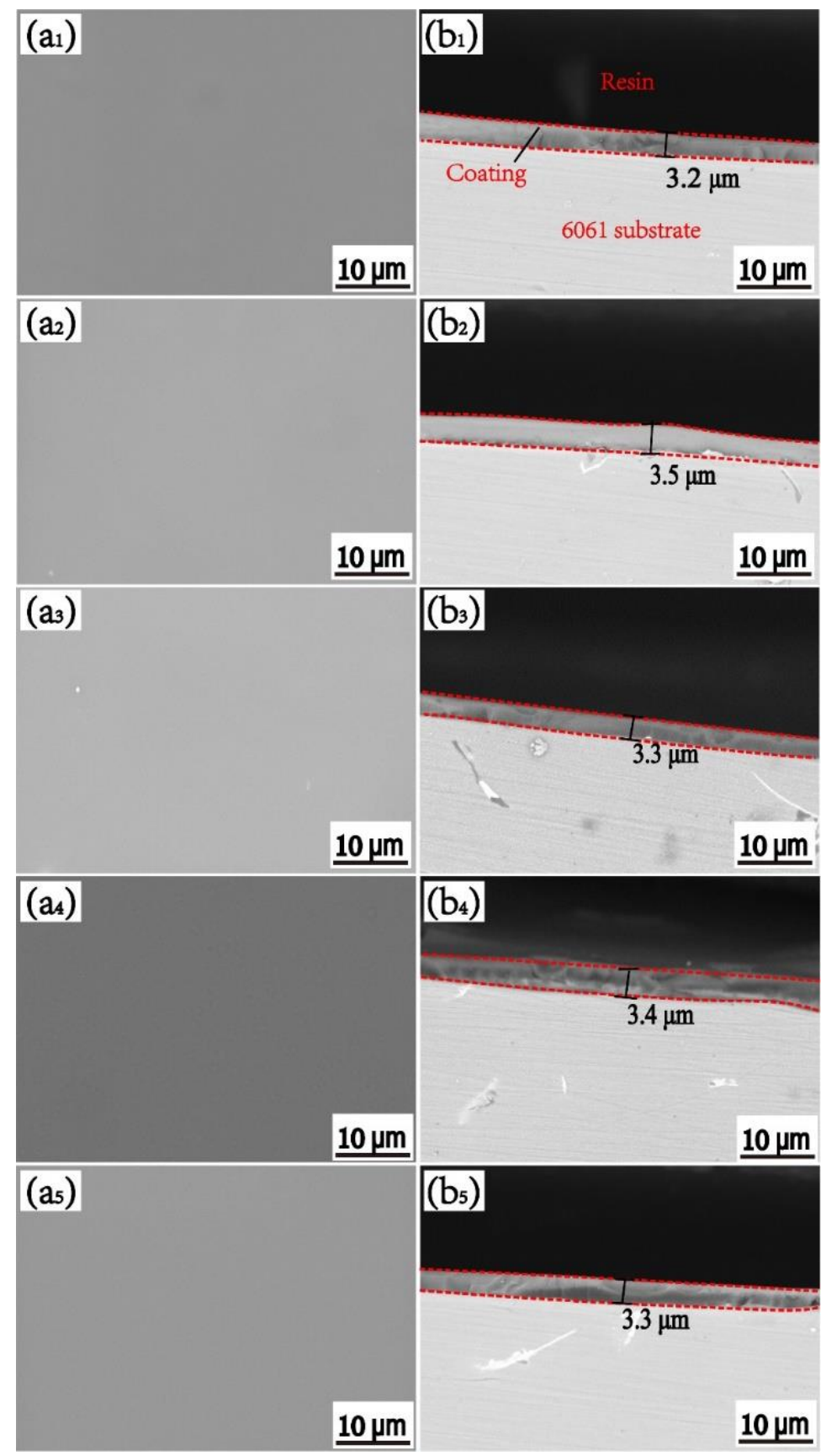

Figure 5. The surface and cross-section morphology of 6061 aluminum alloys with different sol-gel coatings immersed in $3.5 \mathrm{wt} . \% \mathrm{NaCl}$ solution for $0 \mathrm{~h}$, respectively: $\left(\mathbf{a}_{\mathbf{1}}, \mathbf{b}_{\mathbf{1}}\right)$ sol-gel coating unmodified, and sol-gel coating modified with: $\left(\mathbf{a}_{2}, \mathbf{b}_{2}\right) \mathrm{ZnAl-LDHs,}\left(\mathbf{a}_{3}, \mathbf{b}_{3}\right) \mathrm{ZnLaAl}-\mathrm{LDHs}-1 / 5,\left(\mathbf{a}_{4}, \mathbf{b}_{4}\right) \mathrm{ZnLaAl}-$

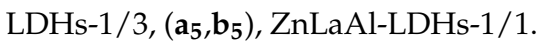




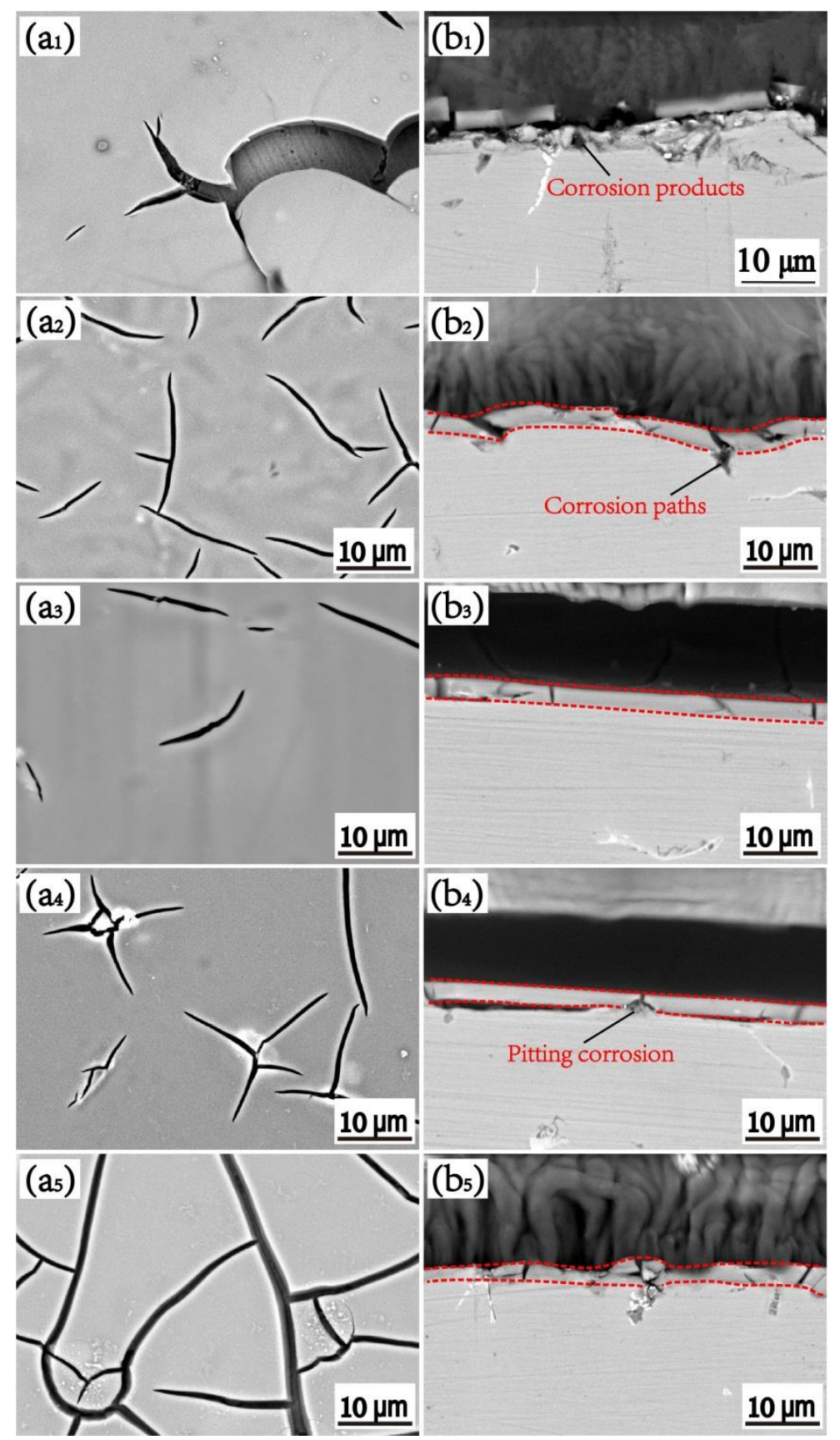

Figure 6. The surface and cross-section morphology of 6061 aluminum alloys with different solgel coatings immersed in $3.5 \mathrm{wt} . \% \mathrm{NaCl}$ solution for $168 \mathrm{~h}$, respectively: $\left(\mathbf{a}_{\mathbf{1}}, \mathbf{b}_{\mathbf{1}}\right)$ sol-gel coating unmodified, and sol-gel coating modified with: $\left(\mathbf{a}_{2}, \mathbf{b}_{2}\right)$ ZnAl-LDHs, $\left(\mathbf{a}_{3}, \mathbf{b}_{3}\right)$ ZnLaAl-LDHs-1/5, $\left(\mathbf{a}_{4}, \mathbf{b}_{4}\right)$ ZnLaAl-LDHs-1/3, $\left(\mathbf{a}_{5}, \mathbf{b}_{5}\right)$, ZnLaAl-LDHs-1/1.

The morphologies of 6061 aluminum alloys with different LDHs/sol-gel coatings after an immersion time of $168 \mathrm{~h}$ are shown in Figure 6. The sol-gel coating has an excellent corrosion protection effect for 6061 aluminum alloys. According to Figure 6, corrosion cracks are found in all sol-gel coatings, and the sol-gel coating without LDHs shows exfoliation. It can be also observed from the cross-section morphology of Figure $6 a_{1}-b_{1}$ that the sol-gel coating without LDHs has obvious fracture phenomenon. The stress corrosion cracking is due to the corrosion products formed on the 6061 aluminum alloys/coating interface during the corrosion process, which pushes the sol-gel coating off the interface and causes the sol-gel coating to lose its protective performance. Compared with sol-gel coating without LDHs, the LDHs/sol-gel (Figure 6) shows better corrosion resistance, the 
stress corrosion cracks of the sol-gel coating are greatly reduced, and the corrosion degree of 6061 aluminium substrate is significantly reduced. This phenomenon can be attributed to the addition of ZnAl-LDHs enhancing the stability of the sol-gel coating.

Compared with ZnAl-LDHs/ sol-gel, fewer cracks are observed in the ZnLaAl-LDHs$1 / 5 /$ sol-gel coatings, which is due to the ability of La doped in ZnAl-LDHs to greatly enhance the stability of the LDHs/sol-gel coating. However, the cracks increase gradually with the increasing of the La-doped content. This is due to the excessive addition of La inhibiting the growth of $\mathrm{ZnLaAl}-\mathrm{LDH}$ and enhancing the content of $\mathrm{ZnO}$, which results in the uniformity of coating being destroyed. ZnLaAl-LDHs has the dual function of capturing $\mathrm{Cl}^{-}$anions and releasing corrosion inhibitor, which delays the diffusion of corrosive $\mathrm{Cl}^{-}$ions to the 6061 aluminum substrate and inhibits the cracking of sol-gel coating.

The EIS of 6061 aluminum alloys with different sol-gel coatings, for different immersion times, is tested to evaluate the long-term corrosion protection performance of the LDHs/sol-gel coatings. Figure 7 shows the equivalent circuits model for EIS data fitting, where $R_{\text {sol }}$ is the solution resistance of the electrolyte; $R_{\mathrm{LDHs}}$ and $C P E_{\mathrm{LDHs}}$ are related to LDHs/sol-gel coating; $R_{\mathrm{OX}}$ and $C P E_{\mathrm{OX}}$ correspond to the resistance and capacitance of $\mathrm{Al}_{2} \mathrm{O}_{3}$ film, respectively; $R_{\mathrm{ct}}$ and $C P E_{\mathrm{dl}}$ represent charge transfer resistance and double-layer capacitance, respectively. In order to better fit the experimental data, a CPE is used instead of the capacitor to compensate for the non-homogeneity in the system. The impedance of $C P E$ is calculated by $Z_{C P E}=\left[Y(j \omega)^{n}\right]^{-1}$, where $Y$ is $C P E$ constant, $\omega$ is frequency and $n$ is dimensionless index $(0 \leq n \leq 1)$, respectively. The CPE are pure resistance and pure capacitance, respectively, when values of $n$ are 0 and 1 .

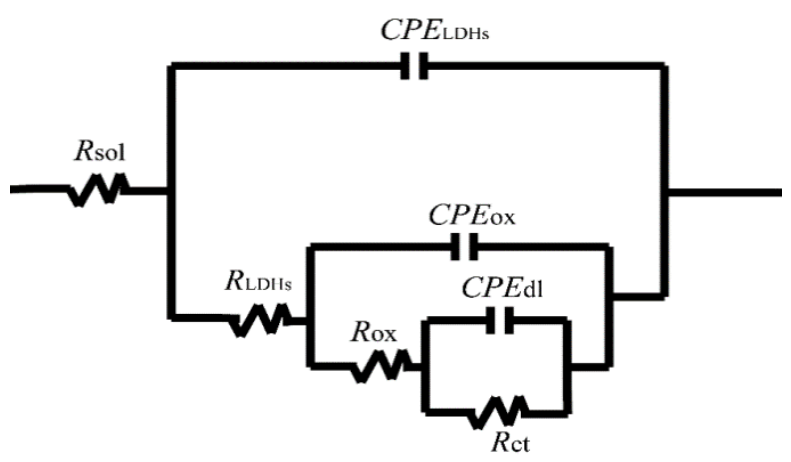

Figure 7. Equivalent circuit models for EIS data fitting.

Table 1 shows the EIS results by fitting the equivalent circuit models. The charge transfer impedance $\left(R_{\mathrm{ct}}\right)$ can be used to reflect the reaction activity at the interface of the coating/6061 aluminum substrate. $R_{\mathrm{ct}}$ decreases with the increasing of immersion time, indicating that the reaction at the interface of the coating/alloys substrate occurs easily during the immersion process. Specifically, the $R_{\mathrm{ct}}$ of LDHs/sol-gel coating is higher than that of sol-gel coating without LDH during the same immersion time, which can be explained by the fact that the interface reactions occur less easily with the addition of LDHs.

The Bode plot diagram (phase angle vs. frequency) is shown in Figure 8, which exhibited three time constants during the immersion process. The first time constant $\left(10^{-2}-10^{-1} \mathrm{~Hz}\right)$ is caused by the electrochemical activity during the corrosion process; the second time constant, at the intermediate frequency $\left(10^{0}-10^{2} \mathrm{~Hz}\right)$, is due to the oxide film between the $\mathrm{Al}$ substrate and sol-gel coating; the last time constant $\left(>10^{4} \mathrm{~Hz}\right)$ corresponds to the electrochemical response of the LDHs/sol-gel coating. 
Table 1. Fitting parameters of different sol-gel coatings using the equivalent circuit in Figure 7.

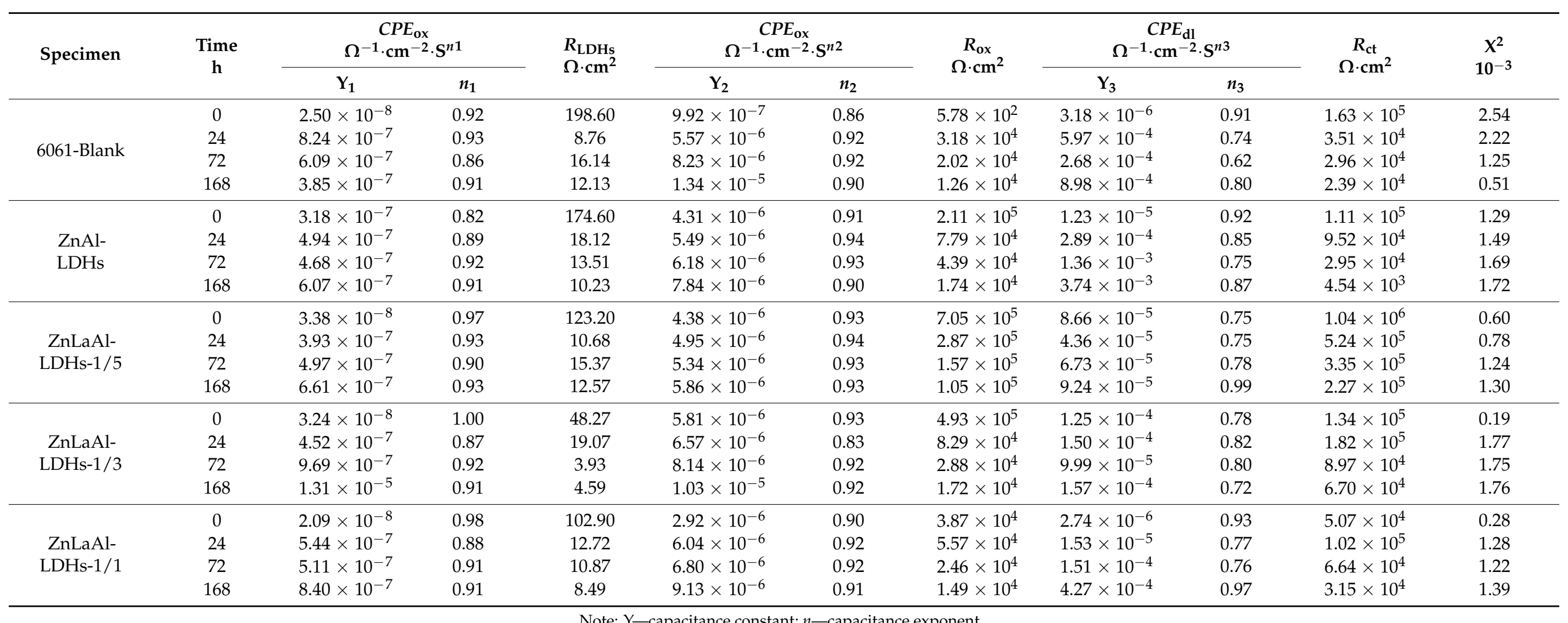


(a)

(b)
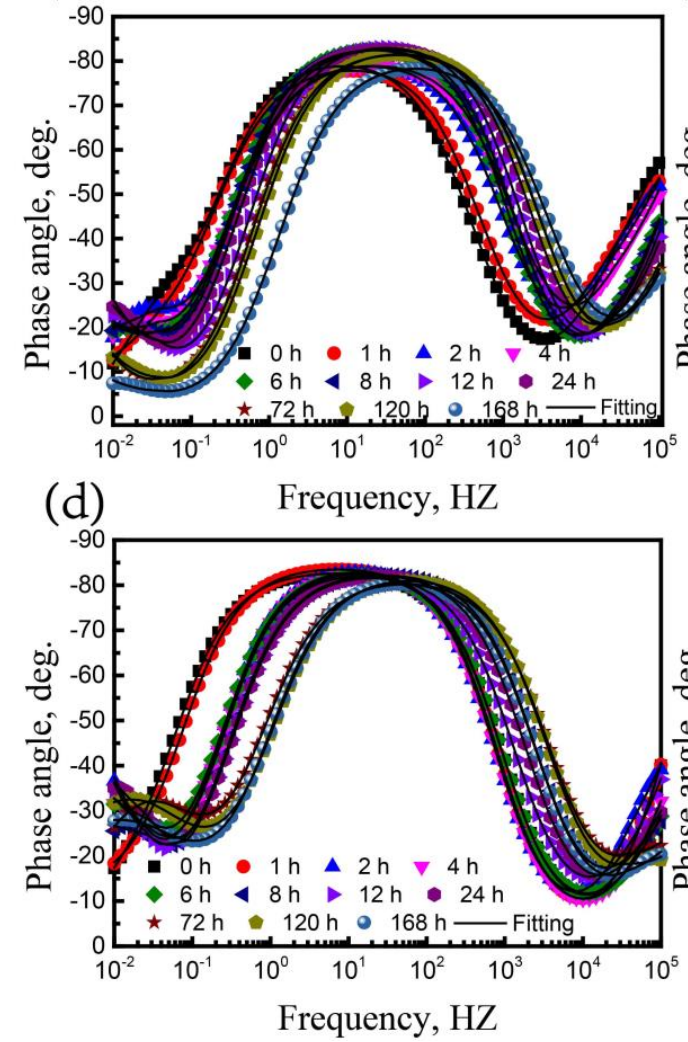

(c)

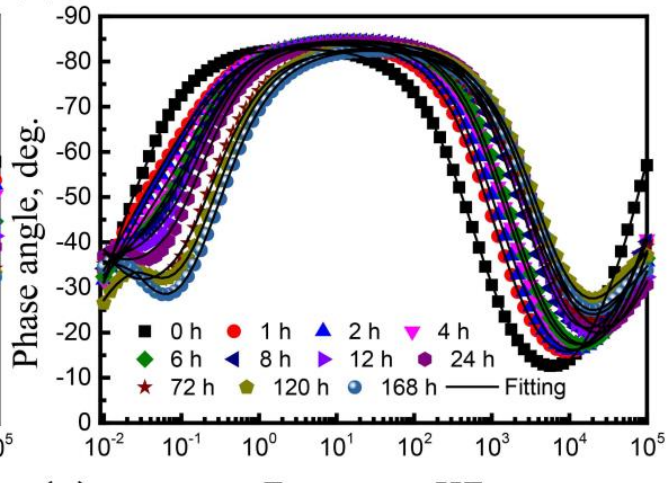

(e)

Frequency, HZ

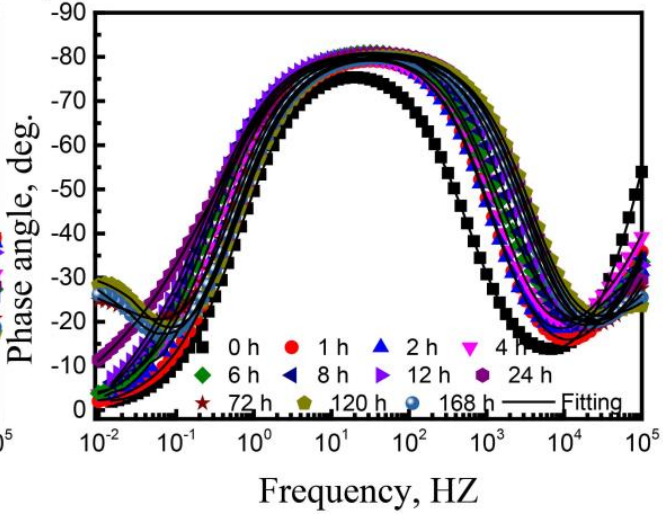

Figure 8. Bode plot (phase angle vs. frequency) of 6061 aluminum alloys with blank sol-gel coating (a), and sol-gel coating modified with: (b) ZnAl-LDHs, (c) ZnLaAl-LDHs-1/5, (d) ZnLaAl-LDHs-1/3, (e) ZnLaAl-LDHs-1/1.

In the test of electrochemical properties, the $|Z|$ at the low frequency of the Bode modulus diagram can be used to estimate the corrosion rate, while the higher $|\mathrm{Z}|$ indicates a lower corrosion rate [39]. As can be seen in Figure 9a-c, the $|Z|$ value of sol-gel coating without LDH is lowest in all specimens and the LDHs/sol-gel coatings have higher values of $|\mathrm{Z}|$. Compared with the $|\mathrm{Z}|$ value of ZnLaAl-LDHs/sol-gel, it can be found that the corrosion resistance gradually decreases with the increasing of the La content, which is due to the excessive addition of La greatly inhibiting the growth of the ZnLaAl-LDHs nanosheet. Moreover, the content of $\mathrm{ZnO}$ increases, which breaks the integrity of the coating and adds coating internal defects. 
(a)

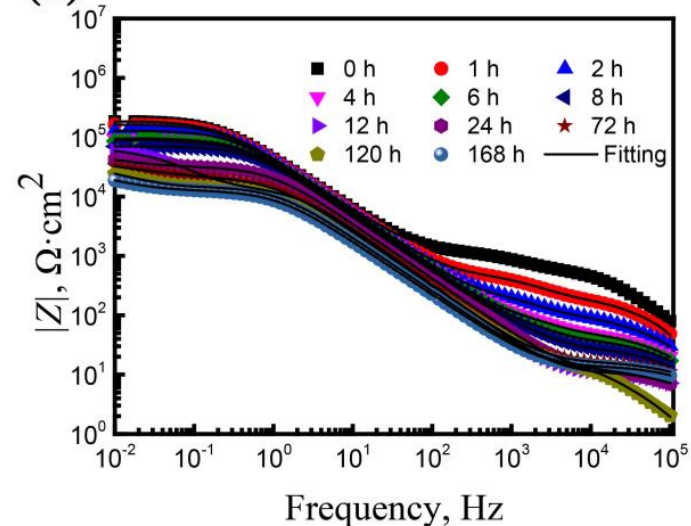

(b)

(c)
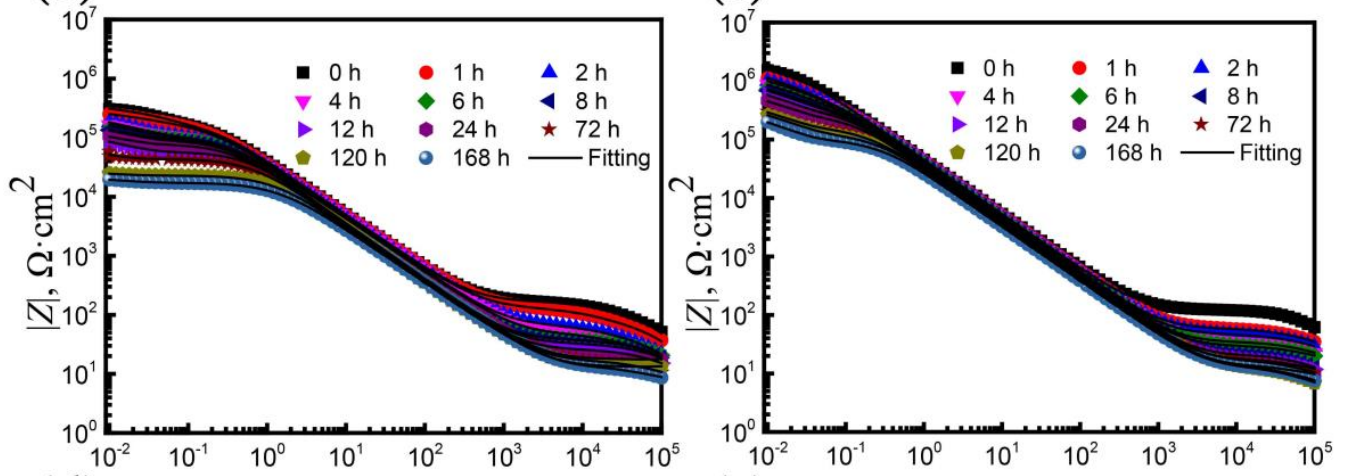

(d)

Frequency, $\mathrm{Hz}$

(e)
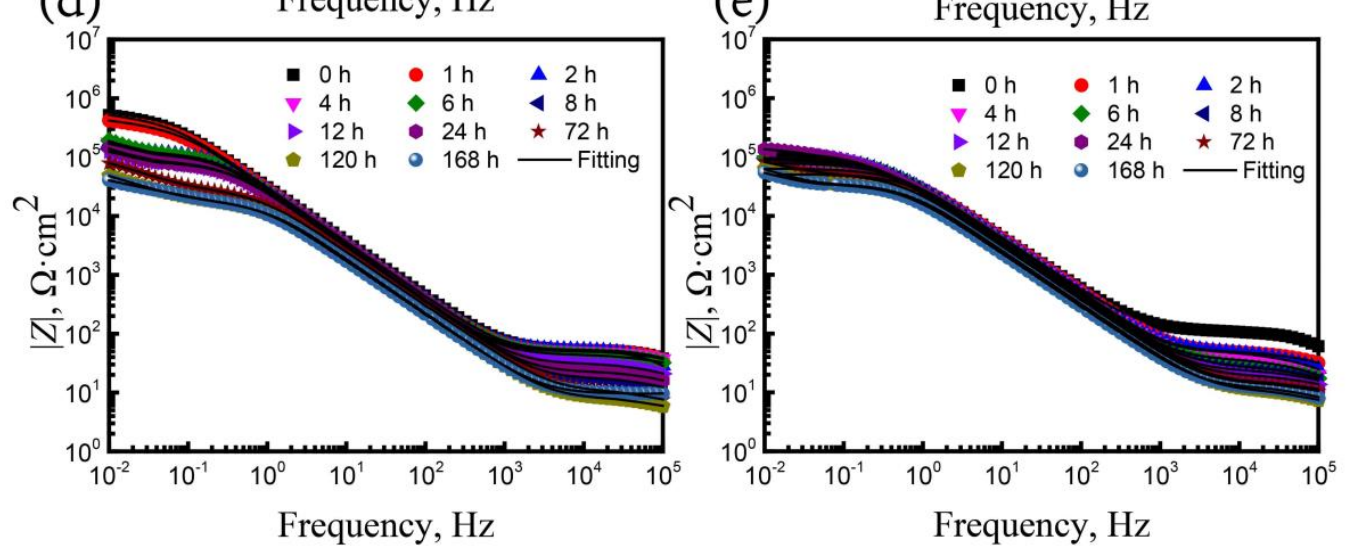

Figure 9. Bode plot (modulus vs. frequency) of 6061 aluminum alloys with blank sol-gel coating (a), and sol-gel coating modified with: (b) ZnAl-LDHs, (c) ZnLaAl-LDHs-1/5, (d) ZnLaAl-LDHs-1/3, (e) ZnLaAl-LDHs-1/1.

The Nyquist diagram (Figure 10) describes the change of impedance of 6061 aluminum alloys with LDHs/sol-gel coating during the corrosion process in $3.5 \mathrm{wt} . \% \mathrm{NaCl}$ solution. The circle radius of the Nyquist diagram is larger, which illustrates that the corrosion protection of coatings is better [40]. It can be seen from the Nyquist diagram that the corrosion resistance of all sol-gel coatings decreases with the increasing of the immersion time. During immersion times of 0-24 h, the corrosion resistance of ZnLaAl-LDHs-1/1/solgel coating increases gradually, which is due to the ZnLaAl-LDHs nanosheets releasing $\mathrm{La}^{3+}$ cations to form the $\mathrm{La}(\mathrm{OH})_{3}$, resulting in self-healing behavior. However, the lowest corrosion resistance of $\mathrm{ZnLaAl}-\mathrm{LDHs}-1 / 1 /$ sol-gel has insufficient protective ability to protect 6061 aluminum substrate. Compared with other specimens, the resistance value of ZnLaAl-LDHs-1/5/sol-gel is highest in all the specimens at the initial stage and after an immersion time of $168 \mathrm{~h}$. The above analysis shows that the La can enhance the 
corrosion resistance of $\mathrm{ZnLaAl-LDHs/sol-gel} \mathrm{coatings} \mathrm{and} \mathrm{reduce} \mathrm{the} \mathrm{corrosion} \mathrm{rate} \mathrm{of}$ the 6061 aluminum substrate, but the excessive addition of La will inhibit the growth of $\mathrm{ZnLaAl}-\mathrm{LDH}$ and enhance the content of $\mathrm{ZnO}$, which results in the uniformity of $\mathrm{ZnLaAl-LDHs/sol-gel} \mathrm{coatings} \mathrm{being} \mathrm{destroyed} \mathrm{and} \mathrm{the} \mathrm{corrosion} \mathrm{resistance} \mathrm{decreasing.}$

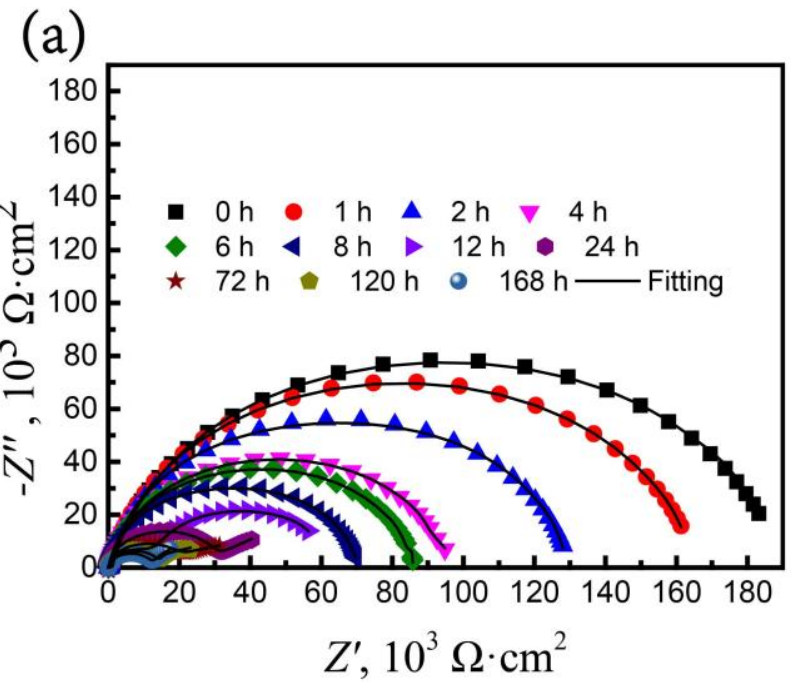

(b)

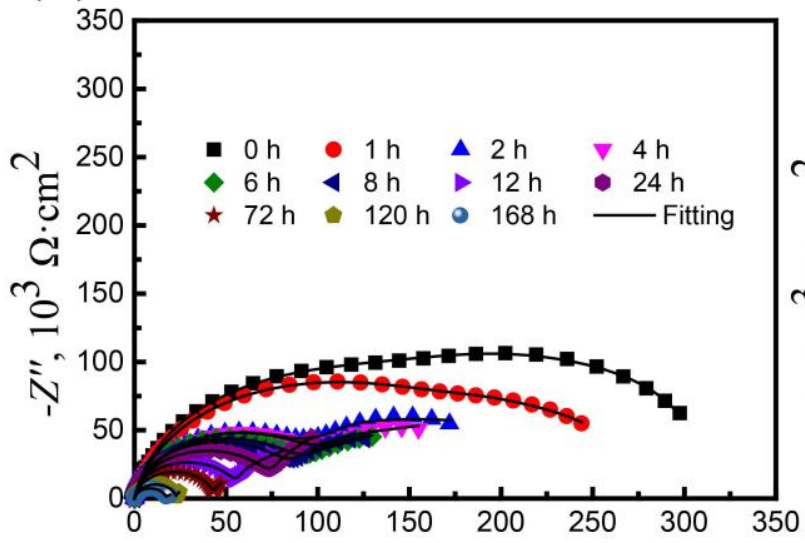

(d)

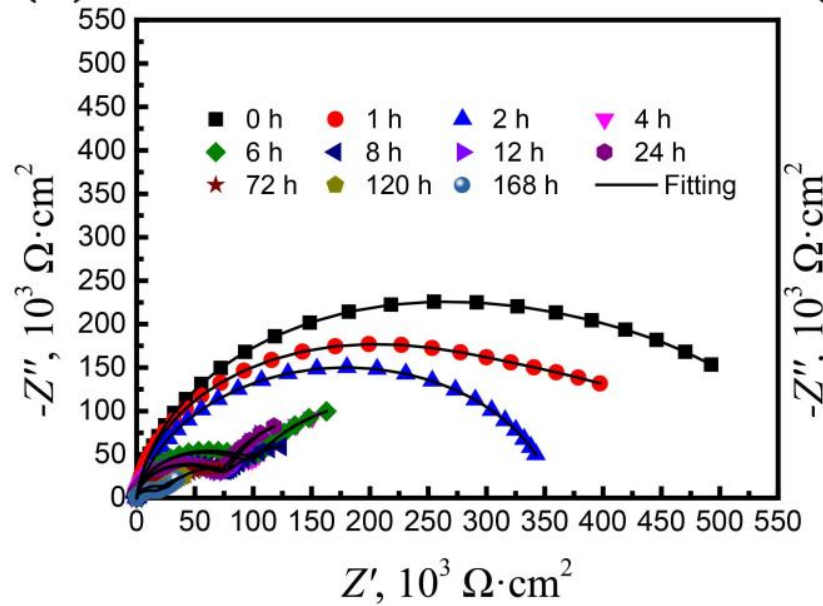

(c)

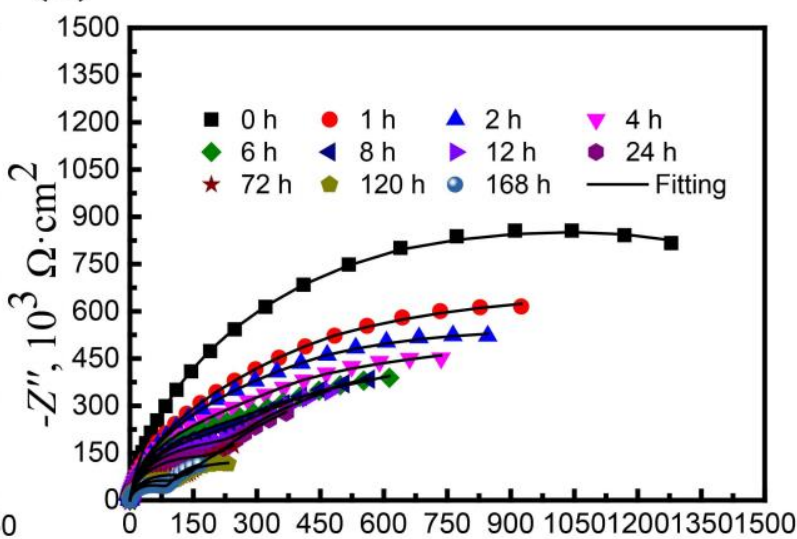

(e) $Z^{\prime}, 10^{3} \Omega \cdot \mathrm{cm}^{2}$

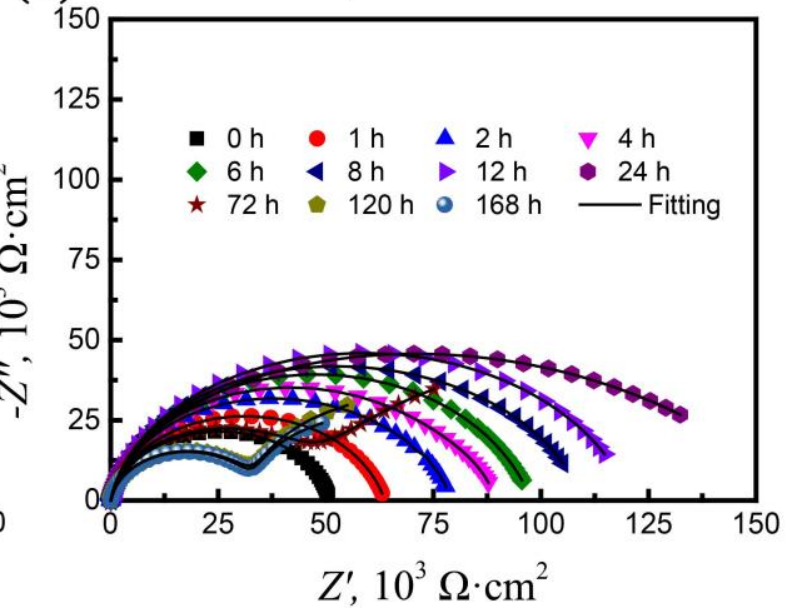

Figure 10. Nyquist spectra of 6061 aluminum alloys with different sol-gel coating (a) blank sol-gel coating, and LDHs/sol-gel coating: (b) ZnAl-LDHs, (c) ZnLaAl-LDHs-1/5, (d) ZnLaAl-LDHs-1/3, (e) ZnLaAl-LDHs-1/1. 


\subsection{Corrosion Mechanism}

The corrosion protection mechanism of $\mathrm{ZnLaAl-LDHs/sol-gel} \mathrm{coating} \mathrm{is} \mathrm{proposed}$ in Figure 11. Due to its density, the ZnLaAl-LDHs/sol-gel coating can be used as a physical barrier to resist the corrosion of chlorine anions (Figure 11a). In addition, the improvement of corrosion performance of $\mathrm{ZnLaAl}-\mathrm{LDH} /$ sol-gel coating is also related to the ion exchange capacity of $\mathrm{ZnLaAl}-\mathrm{LDHs}$ (Figure 11b), namely the adsorption and retention of chlorine anions and the release of $\mathrm{NO}_{3}{ }^{-}[28] . \mathrm{Cl}^{-}$anions are consumed due to the ion exchange property of $\mathrm{ZnLaAl}-\mathrm{LDH}$ during the transfer process of $\mathrm{Cl}^{-}$anions to 6061 aluminum alloys substrate. The ZnLaAl-LDHs/sol-gel coating will show cracks after long-term immersion; the $\mathrm{Cl}^{-}$anions gradually pass through the gap of the coating, and make contact with the aluminum alloys substrate. The pitting corrosion and corrosion products will appear in the interface between sol-gel coating and substrate, pushing the sol-gel coating off the interface (Figure 11c). The corrosion cell will form $\mathrm{OH}^{-}$when $\mathrm{Cl}^{-}$ reacts with aluminum alloys substrate, and it combines with $\mathrm{La}^{3+}$, which is released from ZnLaAl-LDHs to form the insoluble $\mathrm{La}(\mathrm{OH})_{3}$. Finally, $\mathrm{La}(\mathrm{OH})_{3}$ will form a self-healing film to provide secondary protection for the 6061 aluminum alloys substrate (Figure 11d).

(a)

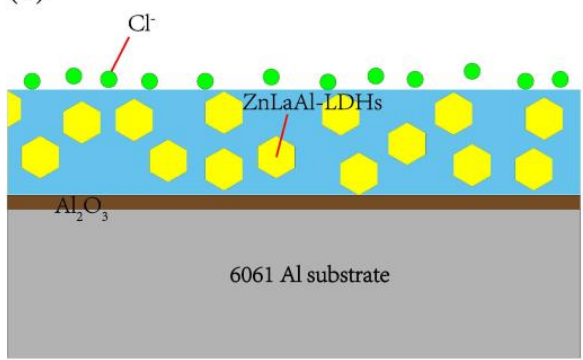

(d)

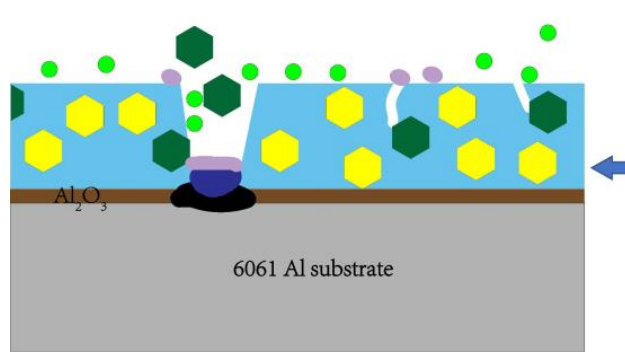

(b)

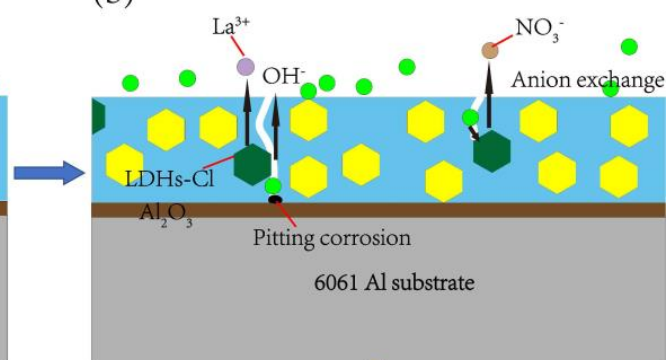

(c)

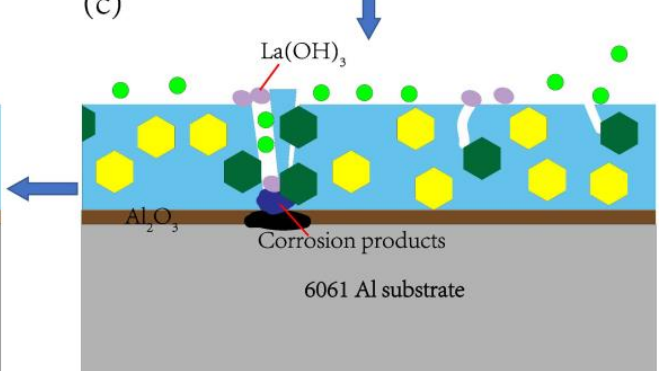

Figure 11. The schematic illustration of the corrosion process of ZnLaAl-LDHs/sol-gel coating, (a-d) the change of corrosion morphology with the increasing of immersion time.

\section{Conclusions}

The sol-gel coatings with La-doped ZnAl-LDHs were prepared on the surface of 6061 aluminum alloys. The aim of this work was to understand the anticorrosion behavior of sol-gel coatings with ZnLaAl-LDHs on 6061 aluminum alloys. The results show that the size of ZnAl-LDHs nanosheets is obviously reduced after the addition of doped $\mathrm{La}$, and this effect will be more and more obvious with the increasing of the La content, which is due to the fact that La can inhibit the growth of LDHs nanosheets and improve its nucleation rate, resulting in the smaller nanosheets of ZnLaAl-LDHs. The corrosion resistance of sol-gel coating with La-doped ZnAl-LDHs has greatly improved, but the corrosion resistance of ZnLaAl-LDHs/sol-gel coating decreases with the increasing of the La content. This phenomenon is due to the excessive La greatly inhibiting the growth of ZnLaAl-LDHs nanosheets, and $\mathrm{Zn}(\mathrm{OH})_{2}$ and $\mathrm{ZnO}$ phases appearing in the precipitate.

The long-term corrosion tests show that ZnAl-LDHs addition can enhance the corrosion resistance of sol-gel coating, and La-doped ZnAl-LDHs can greatly increase this effect. This phenomenon can be explained as follows: (I) the size of ZnLaAl-LDHs nanosheets decreases after La-doping, which causes them to be homogeneously distributed in the 
sol-gel coating and, thus, catch more $\mathrm{Cl}^{-}$anions; (II) the $\mathrm{La}^{3+}$ cation will be released from the $\mathrm{ZnLaAl}-\mathrm{LDHs}$ nanosheets during the corrosion process, and it can form the self-healing film of $\mathrm{La}(\mathrm{OH})_{3}$ to provide secondary protection for 6061 aluminum alloys substrate.

Author Contributions: Data curation, Y.W. (Youbin Wang), B.Z. and Z.Y.; formal analysis, Y.W. (Youbin Wang) and B.Z.; funding acquisition, Y.W. (Youbin Wang) and Y.W. (Yuezhou Wei); investigation, Q.H.; methodology, Q.H.; resources, T.F.; supervision, Y.W. (Youbin Wang); writing-original draft, Q.H.; writing-review \& editing, Y.W. (Youbin Wang). All authors have read and agreed to the published version of the manuscript.

Funding: This work was founded by the Guangxi Natural Science Foundation (Grant No. 2017GXNS FBA198202), the National Natural Science Foundation of China (Grant No. 11975082), and the Guangxi Science and Technology Major Project (Grant No. AA17204100).

Institutional Review Board Statement: Not applicable.

Informed Consent Statement: Not applicable.

Data Availability Statement: The data presented in this study are available in article.

Conflicts of Interest: The authors declare no conflict of interest.

\section{References}

1. Dursun, T.; Soutis, C. Recent developments in advanced aircraft aluminium alloys. Mater. Des. 2014, 56, 862-871. [CrossRef]

2. Heinz, A.; Haszler, A.; Keidel, C.; Moldenhauer, S.; Benedictus, R.; Miller, W.S. Recent development in aluminium alloys for aerospace applications. Mater. Sci. Eng. A 2000, 280, 102-107. [CrossRef]

3. Melchers, R.E. Time dependent development of aluminium pitting corrosion. Adv. Mater. Sci. Eng. 2015, 2015, 215712. [CrossRef]

4. Guillaumin, V.; Mankowski, G. Localized corrosion of 2024 T351 aluminium alloy in chloride media. Corros. Sci. 1999, 41, 421-438. [CrossRef]

5. Srinivasan, P.B.; Heitmann, V.; Dietzel, W. Stress corrosion cracking behaviour of chromated AA2024 T351 alloy in chloride solution. Corros. Eng. Sci. Technol. 2013, 39, 174-176. [CrossRef]

6. Hakimizad, A.; Raeissi, K.; Ashrafizadeh, F. A comparative study of corrosion performance of sealed anodized layers of conventionally colored and interference-colored aluminium. Surf. Coat. Technol. 2012, 206, 4628-4633. [CrossRef]

7. Knudsen, O.Ø.; Tanem, B.S.; Bjørgum, A.; Mårdalen, J.; Hallenstvet, M. Anodising as pre-treatment before organic coating of extruded and cast aluminium alloys. Corros. Sci. 2004, 46, 2081-2095. [CrossRef]

8. Cui, X.; Zhu, G.; Pan, Y.; Shao, Q.; Zhao, C.; Dong, M.; Zhang, Y.; Guo, Z. Polydimethylsiloxane-titania nanocomposite coating: Fabrication and corrosion resistance. Polymer 2018, 138, 203-210. [CrossRef]

9. Kumar, P.; Dehiya, B.S.; Sindhu, A.; Kumar, R.; Pruncu, C.I.; Yadav, A. Fabrication and characterization of silver nanorods incorporated calcium silicate scaffold using polymeric sponge replica technique. Mater. Des. 2020, 195, 109026. [CrossRef]

10. Franquet, A.; le Pen, C.; Terryn, H.; Vereecken, J. Effect of bath concentration and curing time on the structure of non-functional thin organosilane layers on aluminium. Electrochim. Acta 2003, 48, 1245-1255. [CrossRef]

11. Deflorian, F.; Rossi, S.; Fedrizzi, L. Silane pre-treatments on copper and aluminium. Electrochim. Acta 2006, 51, 6097-6103. [CrossRef]

12. Subramanian, V.; van Ooij, W.J. Silane based metal pretreatments as alternatives to chromating: Shortlisted. Surf. Eng. 2013, 15, 168-172. [CrossRef]

13. Campestrini, P.; Terryn, H.; Hovestad, A.; de Wit, J.H.W. Formation of a cerium-based conversion coating on AA2024: Relationship with the microstructure. Surf. Coat. Technol. 2004, 176, 365-381. [CrossRef]

14. Paussa, L.; Rosero-Navarro, N.C.; Andreatta, F.; Castro, Y.; Duran, A.; Aparicio, M.; Fedrizzi, L. Inhibition effect of cerium in hybrid sol-gel films on aluminium alloy AA2024. Surf. Interface Anal. 2010, 42, 299-305. [CrossRef]

15. Mills, S.J.; Christy, A.G.; Genin, J.M.R.; Kameda, T.; Colombo, F. Nomenclature of the hydrotalcite supergroup: Natural layered double hydroxides. Mineral. Mag. 2012, 76, 1289-1336. [CrossRef]

16. Gu, Z.; Atherton, J.J.; Xu, Z.P. Hierarchical layered double hydroxide nanocomposites: Structure, synthesis and applications. Chem. Commun. 2015, 51, 3024-3036. [CrossRef]

17. Bouali, A.C.; Serdechnova, M.; Blawert, C.; Tedim, J.; Ferreira, M.G.S.; Zheludkevich, M.L. Layered double hydroxides (LDHs) as functional materials for the corrosion protection of aluminum alloys: A review. Appl. Mater. Today 2020, 21, 100857. [CrossRef]

18. Zhou, M.; Pang, X.L.; Wei, L.; Gao, K.W. Insitu grown superhydrophobic Zn-Al layered double hydroxides films on magnesium alloy to improve corrosion properties. Appl. Surf. Sci. 2015, 337, 172-177. [CrossRef]

19. Li, Y.; Li, S.; Zhang, Y.; Yu, M.; Liu, J. Enhanced protective Zn-Al layered double hydroxide film fabricated on anodized 2198 aluminum alloy. J. Alloys Compd. 2015, 630, 29-36. [CrossRef] 
20. Smalenskaite, A.; Vieira, D.E.L.; Salak, A.N.; Ferreira, M.G.S.; Katelnikovas, A.; Kareiva, A. A comparative study of coprecipitation and sol-gel synthetic approaches to fabricate cerium-substituted $\mathrm{Mg}$-Al layered double hydroxides with luminescence properties. Appl. Clay Sci. 2017, 143, 175-183. [CrossRef]

21. Zhang, F.; Liu, Z.-G.; Zeng, R.-C.; Li, S.-Q.; Cui, H.-Z.; Song, L.; Han, E.-H. Corrosion resistance of Mg-Al-LDH coating on magnesium alloy AZ31. Surf. Coat. Technol. 2014, 258, 1152-1158. [CrossRef]

22. Gualandi, I.; Monti, M.; Scavetta, E.; Tonelli, D.; Prevot, V.; Mousty, C. Electrodeposition of layered double hydroxides on platinum: Insights into the reactions sequence. Electrochim. Acta 2015, 152, 75-83. [CrossRef]

23. Syu, J.-H.; Uan, J.-Y.; Lin, M.-C.; Lin, Z.-Y. Optically transparent Li-Al-CO 3 layered double hydroxide thin films on an AZ31 Mg alloy formed by electrochemical deposition and their corrosion resistance in a dilute chloride environment. Corros. Sci. 2013, 68, 238-248. [CrossRef]

24. Vega, J.M.; Granizo, N.; de la Fuente, D.; Simancas, J.; Morcillo, M. Corrosion inhibition of aluminum by coatings formulated with Al-Zn-vanadate hydrotalcite. Prog. Org. Coat. 2011, 70, 213-219. [CrossRef]

25. Zhang, Y.; Liu, J.; Li, Y.; Yu, M.; Yin, X.; Li, S. Enhancement of active anticorrosion via Ce-doped Zn-Al layered double hydroxides embedded in sol-gel coatings on aluminum alloy. J. Wuhan Univ. Technol. Mater. Sci. Ed. 2017, 32, 1199-1204. [CrossRef]

26. Zhang, Y.; Yu, P.; Wu, J.; Chen, F.; Li, Y.; Zhang, Y.; Zuo, Y.; Qi, Y. Enhancement of anticorrosion protection via inhibitor-loaded ZnAlCe-LDH nanocontainers embedded in sol-gel coatings. J. Coat. Technol. Res. 2018, 15, 303-313. [CrossRef]

27. Wu, L.; Ding, X.; Zheng, Z.; Tang, A.; Zhang, G.; Atrens, A.; Pan, F. Doublely-doped Mg-Al-Ce- $\mathrm{V}_{2} \mathrm{O}_{7}{ }^{4-} \mathrm{LDH}_{\text {composite film on }}$ magnesium alloy AZ31 for anticorrosion. J. Mater. Sci. Technol. 2021, 64, 66-72. [CrossRef]

28. Zhou, B.; Wei, X.; Wang, Y.; Huang, Q.; Hong, B.; Wei, Y. Effect of lanthanum addition on microstructures and corrosion behavior of ZnAl-LDHs film of 6061 aluminum alloys. Surf. Coat. Technol. 2019, 379, 125056. [CrossRef]

29. Liu, J.; Zhang, Y.; Yu, M.; Li, S.; Xue, B.; Yin, X. Influence of embedded $\mathrm{ZnAlCe}-\mathrm{NO}_{3}{ }^{-}$layered double hydroxides on the anticorrosion properties of sol-gel coatings for aluminum alloy. Prog. Org. Coat. 2015, 81, 93-100. [CrossRef]

30. Yasakau, K.A.; Kuznetsova, A.; Kallip, S.; Starykevich, M.; Tedim, J.; Ferreira, M.G.S.; Zheludkevich, M.L. A novel bilayer system comprising LDH conversion layer and sol-gel coating for active corrosion protection of AA2024. Corros. Sci. 2018, 143, 299-313. [CrossRef]

31. Tedim, J.; Kuznetsova, A.; Salak, A.N.; Montemor, F.; Snihirova, D.; Pilz, M.; Zheludkevich, M.L.; Ferreira, M.G.S. Zn-Al layered double hydroxides as chloride nanotraps in active protective coatings. Corros. Sci. 2012, 55, 1-4. [CrossRef]

32. Velu, S.; Ramkumar, V.; Narayanan, A.; Swamy, C.S. Effect of interlayer anions on the physicochemical properties of zincaluminium hydrotalcite-like compounds. J. Mater. Sci. 1997, 32, 957-964. [CrossRef]

33. Zhang, Y.; Liu, J.; Li, Y.; Yu, M.; Li, S.; Xue, B. Fabrication of inhibitor anion-intercalated layered double hydroxide host films on aluminum alloy 2024 and their anticorrosion properties. J. Coat. Technol. Res. 2015, 12, 293-302. [CrossRef]

34. Duchoslav, J.; Steinberger, R.; Arndt, M.; Keppert, T.; Luckeneder, G.; Stellnberger, K.H.; Hagler, J.; Angeli, G.; Riener, C.K.; Stifter, D. Evolution of the surface chemistry of hot dip galvanized $\mathrm{Zn}-\mathrm{Mg}-\mathrm{Al}$ and $\mathrm{Zn}$ coatings on steel during short term exposure to sodium chloride containing environments. Corros. Sci. 2015, 91, 311-320. [CrossRef]

35. Gao, Y.F.; Nagai, A.; Masuda, Y.; Sato, F.; Seo, W.S.; Koumoto, K. Surface precipitation of highly porous hydrotalcite-like film on $\mathrm{Al}$ from a zinc aqueous solution. Langmuir 2006, 22, 3521-3527. [CrossRef]

36. Salak, A.N.; Tedim, J.; Kuznetsova, A.I.; Vieira, L.G.; Ribeiro, J.L.; Zheludkevich, M.L.; Ferreira, M.G.S. Thermal behavior of layered double hydroxide Zn-Al-pyrovanadate: Composition, structure transformations, and recovering Ability. J. Phys. Chem. C 2013, 117, 4152-4157. [CrossRef]

37. Salak, A.N.; Lisenkov, A.D.; Zheludkevich, M.L.; Ferreira, M.G.S. Carbonate-free Zn-Al (1:1) layered double hydroxide film directly grown on zinc-aluminum alloy coating. ECS Electrochem. Lett. 2014, 3, C9-C11. [CrossRef]

38. Serdechnova, M.; Salak, A.N.; Barbosa, F.S.; Vieira, D.E.L.; Tedim, J.; Zheludkevich, M.L.; Ferreira, M.G.S. Interlayer intercalation and arrangement of 2-mercaptobenzothiazolate and 1,2,3-benzotriazolate anions in layered double hydroxides: In situ X-ray diffraction study. J. Solid State Chem. 2016, 233, 158-165. [CrossRef]

39. Ramezanzadeh, B.; Moghadam, M.H.M.; Shohani, N.; Mahdavian, M. Effects of highly crystalline and conductive polyaniline/graphene oxide composites on the corrosion protection performance of a zinc-rich epoxy coating. Chem. Eng. J. 2017, 320, 363-375. [CrossRef]

40. Alibakhshi, E.; Ghasemi, E.; Mahdavian, M.; Ramezanzadeh, B. A comparative study on corrosion inhibitive effect of nitrate and phosphate intercalated Zn-Al- layered double hydroxides (LDHs) nanocontainers incorporated into a hybrid silane layer and their effect on cathodic delamination of epoxy topcoat. Corros. Sci. 2017, 115, 159-174. [CrossRef] 